ACTA UNIVERSITATIS WRATISLAVIENSIS NO 3792

Slavica Wratislaviensia CLXV • Wrocław 2017

DOI: 10.19195/0137-1150.165.26

\title{
SONJA MILENKOVSKA
}

Istražuvački centar za arealna lingvistika „Božidar Vidoeski”, MANU

Skopje, Republika Macedonii

\section{Да-конструкции како аргументи на предикати од втор ред во минато време (со фокус на ТРЕБА) македонски полски}

Македонските $\partial a$-конструкции се оформиле како репрезенти на субјунктивот (подреден начин за пренесување на информација за нефактивни настани). Станува збор за подредени синтаксички конструкции во функција на реченични аргументи или пропозиции подредени на предикати од повисок ред. Овде ќе стане збор за $\partial a$-конструкции во функција на пропозиционални аргументи на предикати од втор ред. Кај предикатите од втор ред појдовниот аргумент обично е човек, така што содржината на пропозицијата (вториот реченичен аргумент) се всушност неговите мисли, желби, оцени, перцепции... и сл., односно неговиот внатрешен свет. Како такви, пропозициите чии предикати земаат субјунктивен облик не можат да се повикаат на некоја конкретна временска актуализација, така што сами по себе се нефактивни. Ова тврдење се темели на сфаќањето за семантиката на субјунктивот, „дека $\partial a$-конструкциите носат порака за неактуализираниот, нефактивен, вонвременски, иден, повторлив... карактер на настанот, т.е. конституираат несамостојна пропозиција чија модално-темпорална карактеристика зависи од некој надграден предикат“ (Тополињска 2000: 132).

Да-конструкциите имаат широка употреба, „самостојно употребени изразуваат желба, молба, заповед и сл., но најчесто се употребуваат со модални и фазни глаголи.... Се јавуваат со сегашно, со минато определено и во минато неопределено време, но најчесто со сегашното" (Минова-Ѓуркова 1994: 71).

Во оваа статија, во анализата на примерите се вклучени надредени предикати од втор ред претставени со глаголски форми во минато време, во случајот, минати форми од модалниот глагол треба. Овој модален глагол 
изразува деонтичка модалност, односно информира за потребата, должноста, обврската и сл. на реализација на дејството претставено со пропозиционалниот аргумент. Поконкретно, „се работи за наметната должност, за свесна планираност и за примена обврска" (Георгиевски 2009: 20)..., обединето со модалитетот на очекуваност да се врши некоја дејност или да се постигне некоја состојба.

Преку анализата на македонските примери и соодветните преводи на полски јазик целта е да се покаже семантиката и дистрибуцијата на македонските $\partial a$-конструкции како аргументи на надредени предикати од втор ред претставени со глаголските форми на треба во минато време, како и соодветната реализација во полскиот јазик.

1. Предмет на анализа се примери со формите на треба во минато време $+\partial a$-конструкција. Примерите се поделени според различните форми за минато време.

1.1. Требаме + да-конструкција

1.1.1. Во примерите што следуваат се работи за дејства за кои во минатото постоело очекување дека ќе се извршат (во некое идно време во однос на требаше). Но, нивното извршување е прекинато од друго дејство од причини врз кои немаме влијание, а кои се претпоставуваат или подразбираат и често експлицитно се појавуваат во примерите.

Јас требаше да ја добијам Нобеловата награда за мир.

Ja miatam dostać...

Таа требаше да го претставува Косово на „Мис Универзум“во Москва, но преубавата Мирјета на крајот сепак не учествуваше во натпреварот бидејќ Русија не го признава Косово.

Ona miala reprezentować...

Извештајот требаше да биде разгледан од Комисијата вчера, но тоа беше одложено поради, како што рече претседателот на Комисијата Влатко Ѓорчев, неприсуството на специијалната јавна обвинителка Катица Јанева на седницата.

Sprawozdanie miało być wczoraj przejrzane przez Komisję...

Стојанче Стоилов смета дека дефинитивно требаше да го добиеме овој меч.

Stojanczo Stoilow jest zdania, że definitywnie powinniśmy byli wygrać ten $\operatorname{mecz} \ldots$

Македонија одамна требаше да го почне прочесот на преговори за влез во Европската унија.

Macedonia oddawna powinna byla zacząć rozmowy... 
Во овој пример не се знае дали дејството штотуку започнало или воопшто не е започнато.

Во полската реализација примерите се со форми во минато време на miеć чие значење во оваа употреба е дека дејството што претходно било договорено не се исполнило од одредени причини. По нив се примерите со powin(-ien)-na/-o/-y/-i.. + минати форми од być co значење дека неизвршеното дејство во минатото било потребно или должно да се изврши.

1.1.2. Во овој поттип се работи за дејство кое требало да се изврши, но не се извршило во минатото, а наместо тоа говорителот извршил друго дејство поради кое изразува каење. За разлика од примерите во претходниот поттип, овде причината за неизвршување на дејството најчесто е одлуката на самиот говорител (за која подоцна се кае).

Требаше да се насмевнам кога го циитираше омилениот мафијашки филм, наместо да го терам да молчи.

Powinnam byla się uśmiechnąć...

Со слично чувство на каење се и случаите со негација:

Не требаше ниту да му го проверувам мобилниот телефон додека тој ми го подготвуваше појадокот.

Nie trzeba było nawet sprawdzać jego komórki...

Не требаше да бидам толку себична.

Nie powinnam byta być taka egoistka...

Има ситуации и кога говорителот некому друг му наметнува чувство на каење или критика поради неизвршување на одредено дејство.

Требаше да дојдете вчера.

Trzeba byto przyjść...

Полските еквиваленти кои ги изразуваат овие значења се trzeba byto и powin(-ien)-na/-o/-y/-i + минати форми од być.

Во примерите од двата поттипа (1.1.1. и 1.1.2.) говорителот е сведок на неизвршувањето на очекуваните дејства во минатото, а понекогаш и е инволвиран во неизвршувањето.

\section{2. Требал/a/o + да-конструкција}

1.2.1. И кај овие примери се работи за дејства за кои во минатото постоело очекување дека ќе се извршат во некое идно време (во однос на требало), но нивното извршување е прекинато од друго дејство од одредени причини. За 
разлика од примерите во претходниот тип, овде станува збор за прекажување, говорителот не е сведок на неизвршувањето на дејствата во минатото.

Две групи биле подготвени и требало да изведат симултани терористички бомби со саморазнесување и пукање со каламникови во Брисел...

Dwie grupy byly przygotowany i mialy użyć jednocześnie wybuchajacych terorystycznych granatów...

Албанска државјанка која требало да се омажи за македонски државјанин попладнево загина во тешка сообраќајна несреќа...

Obywatelka albańska, która miała wyjść za mąż za obywatela Macedonii...

Така требало да биде.

Tak miato być.

Оружјето е легално, Македонија требала да обезбеди придружба!

Broń jest legalna, Macedonia powinna byla zapewnić eskortę!

Лидерот на грчката опозициска партија Сириза, Алексис Ципрас, во емисија на ТВ Стар, рекол дека грчко-македонскиот спор за името требало да биде решен многу одамна со сложено име со географска одреднииа, пренесе Канал 5.

Aleksys Cipras... powiedziat, że grecko-macedoński spór o imię powinien byt być oddawna rozwiazany.

Рече дека сум требала да дојдам во ноември.

Powiedziat mi, że powinnam byla przyjść w listopadzie.

И овде полската реализација е со форми на минато време на mieć со значење дека дејството што претходно било договорено не се исполнило од одредени причини, како и формите powin(-ien)-na/-o/-y/-i ... + минати форми од być со значење дека неизвршеното дејство во минатото било потребно или должно да се изврши.

1.2.2. Во овој поттип се работи за дејство кое требало да се изврши, но не се извршило, а наместо тоа говорителот можеби несвесно или избрзано извршил некое друго дејство за кое подоцна се преиспитува, се кае.

Може сум требала да напишам некое ливче со потсетување во кујната. Może powinnam byta zostawić w kuchni notatke.

Знам дека сум требала да се борам.

Wiem, że powinnam byla walczyć. 
Во ситуациите кои следуваат говорителот наведува некого да се преиспита или кае за неизвршеното дејство.

Си требал и некоја инспиративна порака да ѝ напишеш.

Powinieneś byt napisać jej i pare slow zachęty.

Си требала на време да се распрашаш пред да го купиш тој велосипед.

Powinnaś była zebrać wcześniej informacje, zanim kupiłaś ten rower.

Не си требал да чекаш.

Nie trzeba (ci) bylo czekać.

Полските еквиваленти кои ги изразуваат овие значења најчесто се powin(-ien)-na/-o/-y/-i + минати форми од być и поретко trzeba byto.

1.3. Во анализата на примерите со треба во минато време $+\partial a$-конструкција треба да се спомнат и оние кои ја вклучуваат партикулата би, односно би mребал/o/a $+\partial a$-конструкција. Со овие формации најчесто се изразуваат дејства, настани потенцијално извршени во минатото, потоа дејства со потенцијал да се извршат во иднина и многу поретко се однесуваат на потенцијални дејства, настани во сегашноста. (Панчевска, Миленковска, во печат)

Од март боледувањата и породилното би требало да се исплаќат редовно.

Od marca chorobowei połogowe powinny być wypłacane regularnie.

Мислам дека секој би требало да има право да се венча без оглед на полот", рече Картер.

Myślę, że każdy powinien mieć prawo do zawarcia matżeństwa...

Петар би требало досега да е вратен.

Piotr powinien by już być z powrotem.

Ана би требало да ги има собрано примерите.

Anna powinna mieć zebrane przykłady.

Овој човек би требало да е некој странец.

Ten człowiek jest chyba cudzoziemcem.

Тоа би требало да е таа приказна.

To by powinna być ta opowieść.

Полската варијанта скоро насекаде е powin(-ien/-na/-o/-y/-i) и ретко во комбинација со $b y$. 
2. Од анализираните примери може да се заклучи дека формите на треба во минато време $+\partial a$-конструкција:

- се употребуваат за изразување на дејства за кои во минатото постоело очекување дека ќе се извршат (во некое идно време во однос на требаше, односно требал,о,a), а чие извршување е прекинато од друго дејство од причини врз кои немаме влијание. Во примерите со требаше $+\partial a$-конструкција говорителот е сведок на неизвршувањето на дејството, што не е случај во примерите со требал, $о, a+\partial a$-конструкција. Полската реализација е со форми во минато време на mіеć со значење дека дејството што претходно било договорено не се исполнило од одредени причини. По нив ce формите powin(-ien)-na/-o/-y/-i... + минати форми од być со значење дека неизвршеното дејство во минатото било потребно или должно да се изврши.

— се употребуваат за изразување на дејство кое говорителот требало да го изврши, но не го извршил, а наместо тоа извршил друго дејство поради кое се кае или преиспитува. Од друга страна, говорителот може и да наведува некого да се кае или преиспитува за одредено неизвршено дејство. Полските еквиваленти кои ги изразуваат овие значења се powin(-ien)-na/-o/-y/-i. + минати форми од być и trzeba byto.

- во комбинација со партикулата би се употребуваат за изразување на дејства потенцијално извршени во минатото, на дејства со потенцијал да се извршат во иднина, и многу ретко за изразување на потенцијални дејства во сегашноста.

\section{Литература}

Георгиевски Г., 2009, Да-реченицата во македонскиот јазик, Скопје: ИМЈ.

Конески Б., 1986, Историја на македонскиот јазик, Скопје: Култура.

Минова-Ѓ уркова Л., 1994, Синтакса на македонскиот стандарден јазик, Скопје: Радинг.

Панчевска А., Миленковска С., 2015, Да-конструкции како аргументи на предикати од втор и трет ред (македонски полски), СУБЈУНКТИВ со посебен осврт на македонските даконструкции, (Морфосинтаксички студии 3), Скопје: МАНУ.

Панчевска А., Миленковска С., Би-конструкиии во и надвор од условен период (македонски полски), Статусот на модалната морфема би во македонскиот јазик и нејзините функционални еквиваленти во другите словенски и несловенски јазици, (Морфосинтаксички студии 4). (во печат)

Тополињска 3., 2000, Полски македонски, Граматичка конфронтаџија 3, Студии од морфосинтаксата, Скопје: МАНУ.

Тополињска 3., 2001, Полски македонски, Граматичка конфронтаиија 5, Реченица во реченицุа, Скопје: МАНУ.

Тополињска 3., 2008, Полски македонски, Граматичка конфронтаиија 8, Развиток на граматичките категории, Студии од морфосинтаксата, Скопје: МАНУ.

Тополињска 3., 2009, Полски македонски, Граматичка конфронтаиија 9, Негација, Скопје: МАНУ.

Чашуле И. 1989, Синтакса на македонската глаголска именка, Скопје: Студентски збор. 


\section{Дa-constructions as argument on the predicates of the second rank in the past tense (with focus on треба)}

\section{Summary}

The aim of the analysis in this paper is to show the semantics and distribution of the Macedonian $\partial a$-constructions as arguments of the predicates of the second rank with past reference. In the focus of the analysis are the main predicates represented with past tense forms of the modal verb треба and the corresponding Polish equivalents.

Keywords: Macedonian $\partial a$-constructions, predicates of the second rank, past tense, modal verb треба, Polish equivalents

\section{Дa-konstrukcje jako argumenty predykatów drugiego rzędu w czasie przeszłym (ze szczególnym uwzględnieniem mреба)}

\section{Streszczenie}

Celem analizy przeprowadzonej w niniejszym artykule jest przedstawienie semantyki i dystrybucji macedońskich $\partial a$-konstrukcji jako argumentów predykatów drugiego rzędu w czasie przeszłym. W centrum analizy znajdują się przykłady zawierające czasownik modalny треба również w czasie przeszłym (reprezentant predykatu głównego) oraz odpowiednie ekwiwalenty polskie.

Stowa kluczowe: macedońskie $\partial a$-konstrukcje, predykaty drugiego rzędu, czas przeszły, czasownik modalny треба, polskie ekwiwalenty 